\title{
CT-Imaging Protocol for Heart Delineation in The Radiation Therapy Preparation Workflow
}

\author{
Sabina Vennarini' ${ }^{1}$, Nathalie Fournier-Bidoz ${ }^{1}$, Vincent Servois ${ }^{1}$, Cynthia Aristei $^{2}$, Anne Stilhart ${ }^{1}$, Francois Campana ${ }^{1}$, Alain Fourquet ${ }^{1}$ and \\ Youlia M. Kirova ${ }^{1 *}$
}

${ }^{1}$ Department of Radiation Oncology, Institut Curie, Paris France

${ }^{2}$ Department of Radiation Oncology, University of Perugia, Italy

Keywords: Breast cancer radiotherapy; Heart; Coronary artery; Delineation

Since CT-based 3D conformal radiation therapy has been in use in radiation therapy (RT), doses to the heart have been collected and attempts were made to correlate them to cardiac disease. Retrospective studies on large populations of patients treated either for breast cancer or for Hodgkin's lymphomas [1-4] showed a correlation between cardiac mortality and dose volume histogram (DVH) or normal tissue complication probability (NTCP) values of the heart. These studies maybe biased by the multiple cofactors of risk in cardiac diseases [2,5]. Moreover, RT-induced toxicities depend on the region of the heart that was irradiated and there is a need for improved imaging protocols to identify the heart substructures such as the coronary arteries. A recent dosimetric study [6] showed that evaluating the dose to the left anterior descending artery (LAD) may change the treatment strategy in breast irradiation. However, planning organ at risk volumes (PRV) must be defined with sufficient margins (ICRU 62) to include motions due to cardiac beating and breathing.

The magnitude of these movements can be evaluated by the use of breath hold (at inhale and at exhale breath times). Cardiac gated CT imaging may be useful to eliminate image blurring and identify the contours of small structures like the coronary arteries which diameter is in the order of the $\mathrm{mm}$. Image resolution in-plane and in the craniocaudal (CC) direction (slice thickness) is one important parameter, as well as collimation width and rotation time. Intra-venous contrast injection should be optimized to obtain a clear visualization of the heart substructures boundaries.

This preliminary study focuses on the establishment of an imaging protocol that could be used in routine for all thorax RT patients, using a large bore CT scanner (Toshiba Aquilion LB, Toshiba Medical, Puteaux, France) installed in the RT department (Table).

\section{Conclusion}

This protocol could be proposed to young patients with left side breast tumors, as well as mediastinal lymphomas. Future evaluation is needed to compare injected and non injected CT scan.

\section{References}

1. Giordano SH, Kuo YF, Freeman JL, Buchholz TA, Hortobagyi GN, et al. (2005) Risk of Cardiac Death After Adjuvant Radiotherapy for Breast Cancer. J Natl Cancer Inst 97: 419-424.

2. Chargari C, Kirov KM, Bollet MA, Magné N, Védrine L, et al. (2011) Cardiac toxicity in breast cancer patients: from a fractional point of view to a global assessment. Cancer Treat Rev 37: 321-330.

3. Kirova YM, de Almeida CE, Canary PC, Kuroki Y, Massabeau C, et al. (2011) Heart, coronaries and breast cancer radiotherapy. Breast 20: 196-197.

4. Kirova YM (2010) Recent advances in breast cancer radiotherapy: Evolution or revolution, or how to decrease cardiac toxicity? World J Radiol 2: 103-108.

5. Feng M, Moran JM, Koelling T, Chughtai A, Chan JL, et al. (2011) Development and Validation of a Heart Atlas To Study Cardiac Exposure to Radiation Following Treatment for Breast Cancer. Int J Radiat Oncol Biol Phys 79: 10-18.

6. de Almeida CE, Fournier-Bidoz N, Massabeau C, Mazal A, Canary PC, et al (2012) Potential benefits of using cardiac gated images to reduce the dose to the left anterior descending coronary during radiotherapy of left breast and internal mammary nodes. Cancer Radiother 16: 44-51.

\begin{tabular}{|c|c|}
\hline \multicolumn{2}{|c|}{ Toshiba 16 detector Aquilion LB (Toshiba Medical, Puteaux, France) } \\
\hline Region & \\
\hline $\begin{array}{l}\text { Direction of acquisition } \\
\text { Breathing status } \\
\text { Scout view } \\
\text { Patient position }\end{array}$ & $\begin{array}{l}\text { CR - CA (cranio-caudal direction) } \\
\text { Free breathing } \\
120 \mathrm{Kv} / 10 \mathrm{~mA} \\
\text { Radiation Treatment position }\end{array}$ \\
\hline $\begin{array}{l}\text { Séries } \\
\text { - Without constrast } \\
\text { - With }\end{array}$ & $\begin{array}{l}2 \text { series } \\
+ \text { One without constrast } \\
+ \text { One with }\end{array}$ \\
\hline $\begin{array}{l}\text { CT acquisition parameters } \\
\text { Acquisition mode } \\
\text { Rotation time } \\
\text { Rotation angle } \\
\text { Collimator width } \\
\text { Slice thickness }(\mathrm{mm}) / \text { Interval } \\
\text { Pitch } \\
\text { Scan field-of-view (SFOV) } \\
\mathrm{kV} / \mathrm{mA}\end{array}$ & $\begin{array}{l}\text { Helical } \\
1.5 \mathrm{sec} \\
360^{\circ} \\
16 \mathrm{~mm} \\
1 \mathrm{~mm} \text { ou } 2 \mathrm{~mm} \\
0.937 \\
\text { Second series (contrast enhanced) FOV } \\
24 \mathrm{~cm}\end{array}$ \\
\hline $\begin{array}{l}\text { CT reconstruction parameters } \\
\text { Acquisition filter } \\
\text { Reconstruction filter } \\
\text { Reconstructed slice thickness and } \\
\text { interval }\end{array}$ & $\begin{array}{l}120 \mathrm{KV} / 250 \mathrm{~mA} \text { ou } 100 \mathrm{~mA} ? \\
\text { Soft tissue standard } \\
\text { FC } 13 \\
3 \mathrm{~mm} \times 3 \mathrm{~mm} \text { ou } 1 \mathrm{~mm} * 1 \mathrm{~mm}\end{array}$ \\
\hline $\begin{array}{l}\text { Contrast concentration } \\
\text { - Quantity (ml) } \\
\begin{aligned} \text { - Rate }(\mathrm{ml} / \mathrm{sec}) \\
\text { - Start }\end{aligned}\end{array}$ & $\begin{array}{l}\text { loméron } 350 \\
90-120 \mathrm{cc} \\
2.5-3 \mathrm{cc} / \mathrm{sec} \text {. } \\
<15-20 \mathrm{sec}\end{array}$ \\
\hline
\end{tabular}

Table 1: Parameters used to image the patients' vessels.

*Corresponding author: Youlia M Kirova, MD, Department of Radiation Oncology, Institut Curie, 26 rue d'Ulm, 75231 Paris Cedex 05, France, Tel: +33 (0)1 443241 93; Fax: +33 (0)15310 46 16; E-mail: youlia.kirova@curie.net

Received May 31, 2012; Accepted June 19, 2012; Published June 23, 2012

Citation: Vennarini S, Fournier-Bidoz N, Servois V, Aristei C, StilhartA, et al. (2012) CT-Imaging Protocol for Heart Delineation in The Radiation Therapy Preparation Workflow. J Nucl Med Radiat Ther S6:007. doi:10.4172/2155-9619.S6-007

Copyright: (c) 2012 Vennarini S, et al. This is an open-access article distributed under the terms of the Creative Commons Attribution License, which permits unrestricted use, distribution, and reproduction in any medium, provided the original author and source are credited. 